Piotr P. Matecki*

\title{
GLÓWNE ELEMENTY METODYCZNE PROCESU PRZYGOTOWYWANIA DANYCH SPRAWOZDAWCZYCH Z ZAKRESU PODATKÓW ZWIĄZANYCH ZE ŚRODOWISKIEM W ŚWIETLE NOWYCH REGULACJI PRAWNYCH UNII EUROPEJSKIEJ
}

\begin{abstract}
Streszczenie. Artykuł poświęcony jest problemom metodycznym dotyczącym procesu przygotowywania danych sprawozdawczych z zakresu podatków związanych ze środowiskiem, obowiązujących w Polsce. Konieczność tworzenia tej sprawozdawczości wynika z nowych regulacji prawnych Unii Europejskiej, które nakładają na kraje członkowskie obowiązek przekazywania odpowiednio przygotowanych danych do Eurostatu. W artykule podjęto próbę rozstrzygnięcia pewnych dylematów metodycznych z tym związanych. W pierwszym rzędzie chodziło o ustalenie listy podatków związanych ze środowiskiem obowiązujących w Polsce, zgodnie z przyjętą definicją Eurostatu. Pozostałe problemy metodyczne, podjęte w artykule, dotyczyły przyporządkowania poszczególnych zidentyfikowanych podatków związanych ze środowiskiem do jednej z czterech grup rodzajowych (energia, transport, zanieczyszczenia środowiska i zasoby naturalne), a następnie - odniesienia ich do wydzielonych grup działalności gospodarczych w Unii Europejskiej (zgodnie z klasyfikacją NACE Rev. 2). Takie przyporządkowanie wymagane jest przez nowe regulacje unijne. W artykule dokonano też analizy obowiązującej, w świetle najnowszej interpretacji Eurostatu, definicji podatków (i opłat) ekologicznych określanych jednolicie jako ,podatki związane ze środowiskiem”. Ponadto zaprezentowano prawne uwarunkowania wiążące się z całym procesem tworzenia sprawozdawczości statystycznej z zakresu tych podatków.
\end{abstract}

Słowa kluczowe: sprawozdawczość statystyczna, podatki związane ze środowiskiem, regulacje prawne, Unia Europejska.

\section{WPROWADZENIE}

Urzędy statystyczne państw członkowskich Unii Europejskiej, w tym także GUS, gromadzą szereg danych statystycznych nie tylko na potrzeby krajowe, lecz także unijne. Dane te dotyczą najróżniejszych obszarów i dziedzin gospodarek narodowych tych krajów. Uzyskane w ten sposób informacje wykorzystywane są do opracowywania propozycji politycznych oraz monitorowania realizacji polity-

\footnotetext{
* Uniwersytet Ekonomiczny w Krakowie, Wydział Finansów, Katedra Polityki Przemysłowej i Ekologicznej.
} 
ki i jej skutków. Obszar prowadzenia sprawozdawczości statystycznej przez GUS na potrzeby Unii Europejskiej (Eurostatu) obejmuje również podatki i opłaty ekologiczne, określane - zgodnie z najnowszą interpretacją - mianem ,podatków związanych ze środowiskiem".

Sprawozdawczość statystyczna z zakresu podatków tego rodzaju, prowadzona dotychczas w Polsce, miała dość ograniczony zakres. Dotyczyła w głównej mierze opłat za korzystanie ze środowiska i innych opłat ekologicznych. Tymczasem najnowsze regulacje prawne Unii Europejskiej poszerzają znacznie zakres wymagań, a nowa przyszła sprawozdawczość statystyczna w dziedzinie podatków związanych ze środowiskiem tworzy wiele dylematów metodycznych. W pierwszym rzędzie są to kwestie interpretacyjne: które obciążenia w postaci podatków, opłat itp. należy uznać za „ekologiczne” - i tym samym uwzględnić w rachunkach? Ale rozwiązania wymaga też problem przyporządkowania zidentyfikowanych podatków związanych ze środowiskiem do jednej z czterech ustalonych kategorii (energia, transport, zanieczyszczenia środowiska, zasoby naturalne), jak też - do określonych grup działalności gospodarczej (zgodnie z klasyfikacją obowiązującą w UE). Celem niniejszego artykułu jest naświetlenie tych problemów i próba wyjaśnienia wątpliwości.

\section{UWARUNKOWANIA PRAWNE TWORZENIA SPRAWOZDAWCZOŚCI STATYSTYCZNEJ Z ZAKRESU PODATKÓW ZWIĄZANYCH ZE ŚRODOWISKIEM}

Pojęcie „podatków związanych ze środowiskiem”, używane w niniejszym artykule, zostało narzucone przez Eurostat. Stanowi ono jednak efekt wieloletnich badań nad istotą i zakresem podatków, nazywanych dotychczas najczęściej podatkami ekologicznymi. Podatki tego rodzaju były bowiem w najróżniejszy sposób interpretowane, definiowane, klasyfikowane itd. W szczególności istotna była przy tym kwestia rozróżnienia pomiędzy podatkami a opłatami ekologicznymi, bądź nazywanymi w inny sposób obciążeniami finansowymi tego rodzaju (należności, narzuty itp.). Dodatkowo, na poziomie Unii Europejskiej problem ten komplikował się ze względu na znaczne zróżnicowanie co do tworzenia, określania i definiowania podatków związanych ze środowiskiem w poszczególnych państwach członkowskich. W konsekwencji, w najnowszej regulacji prawnej UE - Rozporządzeniu Parlamentu Europejskiego i Rady w sprawie europejskich rachunków ekonomicznych środowiska (Dz.U. L 192 z 22.07.2011) - dotyczącej m.in. obowiązków sprawozdawczych z zakresu podatków ekologicznych używa się wyłącznie pojęcia: podatki związane (powiązane, odnoszące się) ze środowiskiem (ang. environmentally related taxes, franc. taxes liées à l'environnement), za które uważa się także inne podobne obciążenia finansowe tego rodzaju (w tym opłaty ekologiczne). Warto dodać, że już wcześniej termin ten występował w ra- 
portach różnych instytucji międzynarodowych (np. Taxation, Innovation and the Environment 2010).

Eurostat w wydanym w 2013 r. uaktualnionym przewodniku metodycznym podaje wprawdzie definicję podatku nazwanego ekologicznym bądź środowiskowym (ang. environmental tax) i określa go jako „taki podatek, dla którego bazą opodatkowania jest jednostka fizyczna (lub substytut jednostki fizycznej) czegoś, co ma udowodniony, specyficzny, negatywny wpływ na środowisko, przy czym podatek ten jest uznawany za podatek w ESA ${ }^{1}$ 95" (Environmental Taxes 2013: 9). Sformułowanie to jest prawie dokładnie powtórzone w Rozporządzeniu Parlamentu Europejskiego i Rady w sprawie europejskich rachunków ekonomicznych środowiska $\mathrm{w}$ odniesieniu do kategorii podatku związanego ze środowiskiem (art. 3), co oznacza podatek lub opłatę, w których podstawą opodatkowania jest jednostka fizyczna (lub odpowiednik jednostki fizycznej) czegoś, co ma udowodniony określony negatywny wpływ na środowisko, i które są uznawane za podatek w systemie ESA 95. Warto zwrócić uwagę, iż w podanej definicji pojawia się termin ,opłata”.

W wyniku obowiązywania wspomnianego rozporządzenia Parlamentu Europejskiego i Rady, kraje członkowskie Unii Europejskiej, w tym także Polska, zobowiązane są do wykonywania rachunków ekonomicznych środowiska. Rozporządzenie to wprowadziło obowiązek sprawozdawczy $\mathrm{w}$ zakresie sporządzania tych rachunków - w tym rachunków podatków związanych ze środowiskiem - i przekazywania danych sprawozdawczych do Komisji Europejskiej (Eurostatu). Polska uzyskała jednak derogację tego obowiązku, w wyniku czego pierwszy rok obligatoryjnego przekazania danych z zakresu podatków związanych ze środowiskiem $\mathrm{w}$ świetle wymienionego rozporządzenia został przesunięty $\mathrm{z}$ roku 2013 na rok 2015.

Rachunki ekonomiczne środowiska EEA (ang. Environmental Economic Accounts) mają być sporządzane w podziale na trzy tzw. moduły. Jednym z nich jest „Moduł podatków związanych ze środowiskiem według rodzajów działalności gospodarczej". Dane statystyczne dotyczące podatków związanych ze środowiskiem, które mają być przekazywane do Eurostatu przez państwa członkowskie, bazują na specjalnie stworzonym do tego celu kwestionariuszu sprawozdawczym. W kwestionariuszu dane o wysokościach środków pochodzących z tych podatków przyporządkowywane są do grup działalności gospodarczych zgodnie z NACE Rev. 2 w tzw. układzie A*64.

NACE (franc. Nomenclature statistique des Activités économiques dans la Communauté Européenne) to stworzona dla potrzeb statystycznych klasyfikacja działalności gospodarczych w Unii Europejskiej. Jest ona zbudowana z szeregu liter i cyfr odpowiadających pięciu poziomom klasyfikacji. NACE Rev. 2 oznacza uaktualnioną (drugą z kolei) wersję tej klasyfikacji, obowiązującą od począt-

\footnotetext{
${ }^{1}$ System Rachunków Narodowych zalecany przez UE (ang. European System of Accounts).
} 
ku 2008 r. W Polsce jej odpowiednikiem jest Polska Klasyfikacja Działalności - PKD 2007. Natomiast układ A*64 to robocza kategoria przyjęta przez Eurostat, wyodrębniona w ramach NACE Rev. 2. Została ona wykorzystana do sporządzania kwestionariusza statystycznego w zakresie podatków związanych ze środowiskiem. A*64 grupuje 99 działów klasyfikacji NACE Rev. 2 w 64 grupach, w efekcie czego niektóre działy są zagregowane. W tab. 1 pokazano klasyfikację NACE Rev. 2 po zagregowaniu niektórych pozycji (rodzajów działalności gospodarczej) zgodnie z układem A*64.

Należy dodać, że podatki powiązane ze środowiskiem przyporządkowywane są do jednej z czterech następujących grup rodzajowych: energia, transport, zanieczyszczenia środowiska i zasoby naturalne. Zaliczenie danego podatku do odpowiedniej grupy rodzajowej podyktowane jest zasadniczo jego podstawą (bazą) opodatkowania. Jednak w niektórych wypadkach nie jest to jednoznaczne. Na przykład akcyza na samochody może być zaliczona do grupy „transport”, ale również do grupy „zanieczyszczenia środowiska”, gdyż eksploatacja samochodów powoduje zanieczyszczenie w postaci emisji do powietrza, jak i hałasu. W przypadku takiej niejednorodnej kategorii podatku należy zastosować zasadę ,,większościową". Sformułowanie to nie jest jednak precyzyjne i wymaga weryfikacji, a ostateczną decyzję podejmuje urząd statystyczny danego kraju. Obowiązują też $\mathrm{w}$ tym względzie pewne reguły ogólne. W szczególności podatki nakładane na paliwa przeznaczane do celów transportowych zaliczane są zawsze do grupy „energia”.

\section{DYLEMATY METODYCZNE I PRÓBA ICH ROZSTRZYGNIĘCIA}

Realizacja narzuconego krajom członkowskim Unii Europejskiej obowiązku wynikającego z Rozporządzenia Parlamentu Europejskiego i Rady w sprawie europejskich rachunków ekonomicznych środowiska implikuje szereg problemów metodycznych. Do najistotniejszych z nich należy zaliczyć:

- ustalenie listy podatków związanych ze środowiskiem (zgodnie z przyjętą definicją Eurostatu) obowiązujących w danym państwie członkowskim Unii Europejskiej,

- przyporządkowanie poszczególnych podatków związanych ze środowiskiem do jednej z czterech wyszczególnionych grup rodzajowych (energia, transport, zanieczyszczenia środowiska i zasoby naturalne),

- przyporządkowanie poszczególnych podatków związanych ze środowiskiem do wydzielonych grup według NACE Rev. 2 w układzie A*64. 
Tabela 1

Klasyfikacja działalności gospodarczych w Unii Europejskiej (NACE Rev. 2) po zagregowaniu według układu $\mathrm{A}^{*} 64$

\begin{tabular}{|c|c|c|}
\hline $\begin{array}{c}\text { Poziom } \\
\text { klasyfikacji }\end{array}$ & Rodzaj działalności & $\begin{array}{l}\text { Numer w klasyfikacji } \\
\text { zgodnie } \mathrm{z} \text { agregacją } \\
\text { A*64 }\end{array}$ \\
\hline 1 & 2 & 3 \\
\hline A & ROLNICTWO, LEŚNICTWO I RYBACTWO & \\
\hline A01 & $\begin{array}{l}\text { Uprawy rolne, chów i hodowla zwierząt, łowiectwo, } \\
\text { włączając działalność usługową }\end{array}$ & 01 \\
\hline $\mathrm{A} 02$ & Leśnictwo i pozyskiwanie drewna & 02 \\
\hline A03 & Rybactwo & 03 \\
\hline B & GÓRNICTWO I WYDOBYWANIE & 05-09 \\
\hline $\mathrm{C}$ & PRZETWÓRSTWO PRZEMYSŁOWE & \\
\hline $\mathrm{C} 10-12$ & $\begin{array}{l}\text { Produkcja artykułów spożywczych, produkcja napojów, } \\
\text { produkcja wyrobów tytoniowych }\end{array}$ & $10-12$ \\
\hline C13-15 & $\begin{array}{l}\text { Produkcja wyrobów tekstylnych, produkcja odzieży, } \\
\text { produkcja skór i wyrobów ze skór wyprawionych }\end{array}$ & $13-15$ \\
\hline $\mathrm{C} 16$ & $\begin{array}{l}\text { Produkcja wyrobów z drewna i korka, z wyłączeniem } \\
\text { mebli; produkcja wyrobów ze słomy i materiałów } \\
\text { używanych do wyplatania }\end{array}$ & 16 \\
\hline $\mathrm{C} 17$ & Produkcja papieru i wyrobów z papieru & 17 \\
\hline $\mathrm{C} 18$ & Poligrafia i reprodukcja zapisanych nośników informacji & 18 \\
\hline C19 & $\begin{array}{l}\text { Wytwarzanie i przetwarzanie koksu i produktów rafinacji } \\
\text { ropy naftowej }\end{array}$ & 19 \\
\hline $\mathrm{C} 20$ & Produkcja chemikaliów i wyrobów chemicznych & 20 \\
\hline $\mathrm{C} 21$ & $\begin{array}{l}\text { Produkcja podstawowych substancji farmaceutycznych } \\
\text { oraz leków i pozostałych wyrobów farmaceutycznych }\end{array}$ & 21 \\
\hline $\mathrm{C} 22$ & Produkcja wyrobów z gumy i tworzyw sztucznych & 22 \\
\hline $\mathrm{C} 23$ & $\begin{array}{l}\text { Produkcja wyrobów z pozostałych mineralnych surowców } \\
\text { niemetalicznych }\end{array}$ & 23 \\
\hline $\mathrm{C} 24$ & Produkcja metali & 24 \\
\hline $\mathrm{C} 25$ & $\begin{array}{l}\text { Produkcja metalowych wyrobów gotowych, } \\
\text { z wyłączeniem maszyn i urządzeń }\end{array}$ & 25 \\
\hline $\mathrm{C} 26$ & $\begin{array}{l}\text { Produkcja komputerów, wyrobów elektronicznych } \\
\text { i optycznych }\end{array}$ & 26 \\
\hline $\mathrm{C} 27$ & Produkcja urządzeń elektrycznych & 27 \\
\hline $\mathrm{C} 28$ & $\begin{array}{l}\text { Produkcja maszyn i urządzeń, gdzie indziej } \\
\text { niesklasyfikowana }\end{array}$ & 28 \\
\hline
\end{tabular}


Tab. 1 (cd.)

\begin{tabular}{|c|c|c|}
\hline 1 & 2 & 3 \\
\hline $\mathrm{C} 29$ & Produkcja pojazdów samochodowych, przyczep i naczep & 29 \\
\hline $\mathrm{C} 30$ & Produkcja pozostałego sprzętu transportowego & 30 \\
\hline C31-32 & Produkcja mebli, produkcja wyrobów i pozostała & $31-32$ \\
\hline $\mathrm{C} 33$ & Naprawa i instalowanie maszyn i urządzeń & 33 \\
\hline $\mathrm{D}$ & $\begin{array}{l}\text { WYTWARZANIE I ZAOPATRYWANIE W ENERGIE } \\
\text { ELEKTRYCZNĄ, GAZ, PARE WODNĄ I POWIETRZE } \\
\text { DO UKŁADÓW KLIMATYZACYJNYCH }\end{array}$ & \\
\hline D35 & $\begin{array}{l}\text { Wytwarzanie i zaopatrywanie w energię elektryczną, gaz, } \\
\text { parę wodną i powietrze do układów klimatyzacyjnych }\end{array}$ & 35 \\
\hline $\mathrm{E}$ & $\begin{array}{l}\text { DOSTAWA WODY; GOSPODAROWANIE ŚCIEKAMI } \\
\text { I ODPADAMI ORAZ DZIAŁALNOŚC ZWIĄZANA } \\
\text { Z REKULTYWACJĄ }\end{array}$ & \\
\hline E36 & Pobór, uzdatnianie i dostarczanie wody & 36 \\
\hline E37-39 & $\begin{array}{l}\text { Odprowadzanie i oczyszczanie ścieków, działalność } \\
\text { związana ze zbieraniem, przetwarzaniem } \\
\text { i unieszkodliwianiem odpadów; odzysk surowców, } \\
\text { działalność związana z rekultywacją i pozostałe usługi } \\
\text { związane z gospodarką odpadami }\end{array}$ & $37-39$ \\
\hline $\mathrm{F}$ & BUDOWNICTWO & \\
\hline F41-43 & $\begin{array}{l}\text { Roboty budowlane związane ze wznoszeniem budynków, } \\
\text { roboty związane z budową obiektów inżynierii lądowej } \\
\text { i wodnej, roboty budowlane specjalistyczne }\end{array}$ & $41-43$ \\
\hline G & $\begin{array}{l}\text { HANDEL HURTOWY I DETALICZNY; NAPRAWA } \\
\text { POJAZDÓW SAMOCHODOWYCH I MOTOCYKLI }\end{array}$ & \\
\hline G45 & $\begin{array}{l}\text { Handel hurtowy i detaliczny pojazdami samochodowymi } \\
\text { i motocyklami; naprawa pojazdów samochodowych } \\
\text { i motocykli }\end{array}$ & 45 \\
\hline G46 & $\begin{array}{l}\text { Handel hurtowy, z wyłączeniem handlu pojazdami } \\
\text { samochodowymi i motocyklami }\end{array}$ & 46 \\
\hline G47 & $\begin{array}{l}\text { Handel detaliczny, z wyłączeniem handlu pojazdami } \\
\text { samochodowymi i motocyklami }\end{array}$ & 47 \\
\hline $\mathrm{H}$ & TRANSPORT I GOSPODARKA MAGAZYNOWA & \\
\hline H49 & Transport lądowy oraz transport rurociągowy & 49 \\
\hline $\mathrm{H} 50$ & Transport wodny & 50 \\
\hline H51 & Transport lotniczy & 51 \\
\hline H52 & $\begin{array}{l}\text { Magazynowanie i działalność usługowa wspomagająca } \\
\text { transport }\end{array}$ & 52 \\
\hline H53 & Działalność pocztowa i kurierska & 53 \\
\hline
\end{tabular}




\begin{tabular}{|c|c|c|}
\hline 1 & 2 & 3 \\
\hline I & $\begin{array}{l}\text { DZIAŁALNOŚĆ ZWIACZANA Z ZAKWATEROWANIEM } \\
\text { I USŁUGAMI GASTRONOMICZNYMI }\end{array}$ & \\
\hline I55-56 & $\begin{array}{l}\text { Zakwaterowanie, działalność usługowa związana } \\
\text { z wyżywieniem }\end{array}$ & $55-56$ \\
\hline $\mathrm{J}$ & INFORMACJA I KOMUNIKACJA & \\
\hline $\mathrm{J} 58$ & Działalność wydawnicza & 58 \\
\hline J59-60 & $\begin{array}{l}\text { Działalność związana z produkcją filmów, nagrań } \\
\text { wideo, programów telewizyjnych, nagrań dźwiękowych } \\
\text { i muzycznych, nadawanie programów ogólnodostępnych } \\
\text { i abonamentowych }\end{array}$ & $59-60$ \\
\hline $\mathrm{J} 61$ & Telekomunikacja & 61 \\
\hline J62-63 & $\begin{array}{l}\text { Działalność związana z oprogramowaniem, doradztwem } \\
\text { w zakresie informatyki i działalności powiązane, } \\
\text { działalność usługowa w zakresie informacji }\end{array}$ & $62-63$ \\
\hline $\mathrm{K}$ & DZIAŁALNOŚĆ FINANSOWA I UBEZPIECZENIOWA & \\
\hline K64 & $\begin{array}{l}\text { Finansowa działalność usługowa, z wyłączeniem } \\
\text { ubezpieczeń i funduszy emerytalnych }\end{array}$ & 64 \\
\hline K65 & $\begin{array}{l}\text { Ubezpieczenia, reasekuracja oraz fundusze emerytalne, } \\
\text { z wyłączeniem obowiązkowego ubezpieczenia } \\
\text { społecznego }\end{array}$ & 65 \\
\hline K66 & $\begin{array}{l}\text { Działalność wspomagająca usługi finansowe, } \\
\text { ubezpieczenia i fundusze emerytalne }\end{array}$ & 66 \\
\hline $\mathrm{L}$ & $\begin{array}{l}\text { DZIAŁALNOŚĆ ZWIAZANA Z OBSŁUGĄ RYNKU } \\
\text { NIERUCHOMOŚCI }\end{array}$ & \\
\hline L68 & Działalność związana z obsługą rynku nieruchomości & 68 \\
\hline M & $\begin{array}{l}\text { DZIAŁALNOŚĆ PROFESJONALNA, NAUKOWA } \\
\text { I TECHNICZNA }\end{array}$ & \\
\hline M69-70 & $\begin{array}{l}\text { Działalność prawnicza, rachunkowo-księgowa i doradztwo } \\
\text { podatkowe, działalność firm centralnych (head offices); } \\
\text { doradztwo związane z zarządzaniem }\end{array}$ & $69-70$ \\
\hline M71 & $\begin{array}{l}\text { Działalność w zakresie architektury i inżynierii; badania } \\
\text { i analizy techniczne }\end{array}$ & 71 \\
\hline M72 & Badania naukowe i prace rozwojowe & 72 \\
\hline M73 & Reklama, badanie rynku i opinii publicznej & 73 \\
\hline M74-75 & $\begin{array}{l}\text { Działalność profesjonalna, naukowa i techniczna, } \\
\text { pozostała, działalność weterynaryjna }\end{array}$ & $74-75$ \\
\hline $\mathrm{N}$ & $\begin{array}{l}\text { DZIAŁALNOŚĆ W ZAKRESIE USŁUG } \\
\text { ADMINISTROWANIA I DZIAŁALNOŚĆ } \\
\text { WSPIERAJĄCA }\end{array}$ & \\
\hline N77 & Wynajem i dzierżawa & 77 \\
\hline N78 & Działalność związana z zatrudnieniem & 78 \\
\hline
\end{tabular}


Tab. 1 (cd.)

\begin{tabular}{|c|c|c|}
\hline 1 & 2 & 3 \\
\hline N79 & $\begin{array}{l}\text { Działalność organizatorów turystyki, pośredników i agen- } \\
\text { tów turystycznych oraz pozostała działalność usługowa } \\
\text { w zakresie rezerwacji i działalności z nią związane }\end{array}$ & 79 \\
\hline N80-82 & $\begin{array}{l}\text { Działalność detektywistyczna i ochroniarska, działalność } \\
\text { usługowa związana z utrzymaniem porządku w budynkach } \\
\text { i zagospodarowaniem terenów zieleni, działalność związa- } \\
\text { na z administracyjną obsługą biura i pozostała działalność } \\
\text { wspomagająca prowadzenie działalności gospodarczej }\end{array}$ & $80-82$ \\
\hline $\mathrm{O}$ & $\begin{array}{l}\text { ADMINISTRACJA PUBLICZNA I OBRONA } \\
\text { NARODOWA; OBOWIĄZKOWE UBEZPIECZENIA } \\
\text { SPOŁECZNE }\end{array}$ & \\
\hline O84 & $\begin{array}{l}\text { Administracja publiczna i obrona narodowa; obowiązkowe } \\
\text { ubezpieczenia społeczne }\end{array}$ & 84 \\
\hline $\mathrm{P}$ & EDUKACJA & \\
\hline P85 & Edukacja & 85 \\
\hline Q & OPIEKA ZDROWOTNA I POMOC SPOŁECZNA & \\
\hline Q86 & Opieka zdrowotna & 86 \\
\hline Q87-88 & $\begin{array}{l}\text { Pomoc społeczna } \mathrm{z} \text { zakwaterowaniem, pomoc społeczna } \\
\text { bez zakwaterowania }\end{array}$ & $87-88$ \\
\hline $\mathrm{R}$ & $\begin{array}{l}\text { DZIAŁALNOŚĆ ZWIĄZANA Z KULTURĄ, ROZRYW- } \\
\text { KĄ I REKREACJĄ }\end{array}$ & \\
\hline R90-92 & $\begin{array}{l}\text { Działalność twórcza związana z kulturą i rozrywką, dzia- } \\
\text { łalność bibliotek, archiwów, muzeów oraz pozostała dzia- } \\
\text { łalność związana z kulturą, działalność związana z grami } \\
\text { losowymi i zakładami wzajemnymi }\end{array}$ & $90-92$ \\
\hline R93 & Działalność sportowa, rozrywkowa i rekreacyjna & 93 \\
\hline $\mathrm{S}$ & POZOSTAŁA DZIAŁALNOŚĆ USŁUGOWA & \\
\hline S94 & Działalność organizacji członkowskich & 94 \\
\hline S95 & $\begin{array}{l}\text { Naprawa komputerów i artykułów użytku osobistego i do- } \\
\text { mowego }\end{array}$ & 95 \\
\hline S96 & Działalność usługowa indywidualna, pozostała & 96 \\
\hline $\mathrm{T}$ & $\begin{array}{l}\text { GOSPODARSTWA DOMOWE ZATRUDNIAJĄCE PRA- } \\
\text { COWNIKÓW; GOSPODARSTWA DOMOWE PRODU- } \\
\text { KUJĄCE WYROBY I ŚWIADCZĄCE USŁUGI NAWŁA- } \\
\text { SNE POTRZEBY }\end{array}$ & \\
\hline T97-98 & $\begin{array}{l}\text { Gospodarstwa domowe zatrudniające pracowników, gospo- } \\
\text { darstwa domowe produkujące wyroby i świadczące usługi } \\
\text { na własne potrzeby }\end{array}$ & $97-98$ \\
\hline $\mathrm{U}$ & ORGANIZACJE I ZESPOŁY EKSTERYTORIALNE & \\
\hline U99 & Organizacje i zespoły eksterytorialne & 99 \\
\hline
\end{tabular}

Źródło: Małecki (2012a): 30-33. 
Lista podatków związanych ze środowiskiem obowiązujących w Polsce, przyjęta przez GUS do celów sprawozdawczych wynikających z nowych regulacji prawnych Unii Europejskiej, została wypracowana w oparciu o dotychczasowe badania naukowe z tego zakresu (m.in. Małecki 2012b; Bartniczak, Ptak 2011), opracowania i interpretacje Eurostatu ${ }^{2}$, jak również opinie powołanej przez Prezesa GUS specjalnej Grupy Zadaniowej ds. Rachunków Środowiskowych. Ostateczny skład listy, w oparciu o którą tworzone będą dane sprawozdawcze, zaprezentowano w tab. 2. Jak widać, lista ta zawiera 22 pozycje. Ich krótka charakterystyka przedstawia się następująco3.

Do produktów szkodliwych dla środowiska i objętych podatkiem akcyzowym zalicza się wszelkiego rodzaju paliwa przeznaczone do celów opałowych lub napędowych, w tym także gaz LPG, jak również energię elektryczną i samochody osobowe. Stawki akcyzy są zróżnicowane, a ich wysokość uwzględnia stopień oddziaływania na środowisko. Obowiązanymi do uiszczania akcyzy na wymienione produkty są wszystkie podmioty, które dokonują czynności podlegających opodatkowaniu tym podatkiem. Podatek akcyzowy stanowi dochód budżetu państwa. Natomiast organami podatkowymi właściwymi w zakresie tego podatku są urzędy celne i izby celne. Podatnicy są zobowiązani do wpłacania należności z tytułu akcyzy na rachunek bankowy właściwej terytorialnie izby celnej.

Opłaty celne na importowane produkty szkodliwe dla środowiska dotyczą dwóch grup. Pierwsza obejmuje paliwa mineralne, oleje mineralne i produkty ich destylacji, substancje bitumiczne, woski mineralne, zaś druga - pojazdy, statki powietrzne, jednostki pływające i współdziałające urządzenia transportowe. Opłaty celne nakładane na wymienione produkty uiszczane są na rzecz budżetu państwa przez podmioty dokonujące transakcji zagranicznej w postaci importu. Organami podatkowymi właściwymi w zakresie należności celnych są urzędy celne i izby celne.

Opłaty rejestracyjne oraz ewidencyjne pobierane są przy rejestracji pojazdów. W skład opłat rejestracyjnych wchodzą opłaty za wydanie dowodu rejestracyjnego, pozwolenia czasowego i tablic rejestracyjnych. Ponadto, przy rejestracji samochodu pobierana jest jeszcze opłata ewidencyjna za wydanie dowodu rejestracyjnego, pozwolenia czasowego, zalegalizowanych tablic rejestracyjnych i nalepki kontrolnej. Wszystkie opłaty rejestracyjne i ewidencyjne pojazdów pobierane są przez właściwy terytorialnie urząd powiatowy.

Opodatkowaniu podatkiem od środków transportowych podlegają samochody ciężarowe, ciągniki siodłowe i balastowe, przyczepy i naczepy oraz autobusy. W ramach tych grup występuje zróżnicowanie stawek podatku, głównie w zależności od wielkości pojazdu, ale i niekiedy dodatkowo (stawki określają samodzielnie gminy) - od oddziaływania na środowisko. Podatek od środków transportowych zobowiązani są uiszczać właściciele środków transportowych (osoby fizyczne i prawne). Należność z tytułu tego podatku przekazywana jest na rachunek bankowy właściwego terytorialnie urzędu gminy.

\footnotetext{
2 Przekazane także w trakcie szkoleń i konsultacji pracowników GUS.

3 Niektóre z tych pozycji zostały opisane łącznie.
} 
Tabela 2

Lista obowiązujących w Polsce podatków związanych ze środowiskiem przyjęta przez GUS na potrzeby sprawozdawczości Eurostatu

\begin{tabular}{|l|l|}
\hline \multicolumn{1}{|c|}{ Podatek związany ze środowiskiem } & $\begin{array}{c}\text { Przyporządkowanie } \\
\text { do grupy rodzajowej }\end{array}$ \\
\hline Akcyza na paliwa przeznaczone do celów opałowych & $\mathrm{E}$ \\
\hline Akcyza na paliwa przeznaczone do celów napędowych & $\mathrm{E}$ \\
\hline Akcyza na gaz LPG & $\mathrm{E}$ \\
\hline Akcyza na energię elektryczną & $\mathrm{E}$ \\
\hline Akcyza na samochody osobowe & $\mathrm{T}$ \\
\hline Akcyza na oleje smarowe & $\mathrm{P}$ \\
\hline $\begin{array}{l}\text { Opłaty celne na importowane: paliwa mineralne, oleje mineralne } \\
\text { i produkty ich destylacji, substancje bitumiczne, woski mineralne }\end{array}$ & $\mathrm{E}$ \\
\hline $\begin{array}{l}\text { Opłaty celne na importowane: pojazdy, statki powietrzne, jednostki } \\
\text { pływające oraz współdziałające urządzenia transportowe }\end{array}$ & $\mathrm{T}$ \\
\hline Opłaty rejestracyjne i ewidencyjne pojazdów & $\mathrm{T}$ \\
\hline Podatek od środków transportowych & $\mathrm{T}$ \\
\hline Opłaty za odprowadzanie ścieków & $\mathrm{P}$ \\
\hline Opłaty za emisję gazów i pyłów & $\mathrm{P}$ \\
\hline Opłaty produktowe za opakowania & $\mathrm{P}$ \\
\hline Opłaty produktowe za oleje smarowe & $\mathrm{P}$ \\
\hline Opłaty produktowe za opony & $\mathrm{P}$ \\
\hline Opłaty produktowe za baterie i akumulatory & $\mathrm{P}$ \\
\hline Opłaty za zużyty sprzęt elektryczny i elektroniczny & $\mathrm{P}$ \\
\hline Opłaty za usuwanie drzew i krzewów & $\mathrm{R}$ \\
\hline Opłaty za brak sieci zbierania wyeksploatowanych pojazdów & $\mathrm{T}$ \\
\hline Opłaty za substancje zubożające warstwę ozonową & $\mathrm{P}$ \\
\hline Opłaty zastępcze za niewykupienie wymaganej ilości energii odnawialnej & $\mathrm{E}$ \\
\hline Opłata paliwowa & $\mathrm{T}$ \\
\hline
\end{tabular}

${ }^{a} \mathrm{E}$ - energia; $\mathrm{T}$ - transport; $\mathrm{P}$ - zanieczyszczenia (ang. pollution), $\mathrm{R}$ - zasoby (ang. resources).

Źródło: opracowanie własne na podstawie: Małecki (2013): 13-14.

Opłaty za odprowadzanie ścieków do wód i ziemi stanowią jeden z czterech rodzajów opłat za korzystanie ze środowiska, obok opłat za: pobór wody podziemnej i powierzchniowej, emisję gazów i pyłów oraz składowanie odpadów ${ }^{4}$.

\footnotetext{
${ }^{4}$ Opłat za składowanie odpadów nie zalicza się - zgodnie z metodologią Eurostatu - do podatków powiązanych ze środowiskiem.
} 
Opłaty za korzystanie ze środowiska mają obowiązek ponosić wszystkie podmioty (głównie gospodarcze), które wykorzystują zasoby środowiskowe do celów prowadzonej działalności produkcyjnej oraz aktywności pozaprodukcyjnej. Podmioty te mają we własnym zakresie dokonać naliczenia należnej opłaty i przekazania jej na konto bankowe właściwego urzędu marszałkowskiego. Ostatecznymi adresatami środków z opłat za korzystanie ze środowiska są - w odpowiedniej proporcji - Narodowy Fundusz Ochrony Środowiska i Gospodarki Wodnej, wojewódzkie fundusze ochrony środowiska i gospodarki wodnej oraz budżety powiatów i gmin ${ }^{5}$.

Do ścieków objętych opłatami za odprowadzanie do wód i ziemi zalicza się: wody zużyte na cele gospodarcze lub bytowe, ciekłe odchody zwierzęce, wody opadowe lub roztopowe, wody odciekowe ze składowisk odpadów, wykorzystane solanki, wody lecznicze i termalne, wody pochodzące z odwodnienia zakładów górniczych oraz ścieki odprowadzane z obiektów chowu lub hodowli ryb i innych organizmów wodnych. Ustalanie wysokości opłat za odprowadzanie ścieków jest skomplikowane i zależy od rodzaju substancji zawartych w ściekach i ich ilości, od rodzaju ścieków, a w przypadku wód chłodniczych - od temperatury. Opłaty za zrzut ścieków skalkulowane są głównie w odniesieniu do czterech wskaźników charakteryzujących substancje zawarte w ściekach, tj. pięciodobowe biochemiczne zapotrzebowanie na tlen (BZT5), chemiczne zapotrzebowanie na tlen (ChZT), zawiesina ogólna oraz suma chlorków i siarczanów.

Opłaty za emisję gazów i pyłów objęte są analogiczną procedurą co do obowiązku ich uiszczania, naliczania i przekazywania, jak pozostałe opłaty za korzystanie ze środowiska. Opłatami tymi objętych jest 67 substancji lotnych. Wysokość opłaty zależy od ilości i rodzaju wprowadzanych do powietrza substancji tego typu. Stawki opłat są uzależnione od stopnia oddziaływania na środowisko. Opłaty związane z emisją gazów i pyłów do powietrza pobierane są także wówczas, gdy nie ma możliwości ustalenia wprost ich rodzaju oraz ilości. Dotyczy to spalania różnego rodzaju paliw w mniejszych kotłach (o mocy cieplnej do $5 \mathrm{MW}$ ) oraz spalania paliw w silnikach spalinowych, jak również przeładunku benzyn silnikowych oraz chowu i hodowli drobiu.

Obowiązujący w Polsce system opłat produktowych (za opakowania, baterie i akumulatory, oleje smarowe, opony) polega na ścisłym powiązaniu z obowiązkiem odzysku i recyklingu, a także zbiórki niektórych odpadów. Przedsiębiorcy wprowadzający na polski rynek produkty w opakowaniach (z tworzyw sztucznych, aluminium, stali, papieru i tektury, szkła i drewna) oraz wybrane szkodliwe dla środowiska produkty (baterie i akumulatory, oleje smarowe, opony) mają obowiązek zrealizowania w ciągu roku określonych poziomów odzysku i recyklingu odpadów opakowaniowych (pochodzących z opakowań produktów) oraz poużytkowych (pochodzących ze skonsumowanych produktów). W przypadku

\footnotetext{
${ }^{5}$ Do końca 2009 r. powiatowe i gminne fundusze ochrony środowiska i gospodarki wodnej.
} 
niezrealizowania bądź zrealizowania tylko w części tego obowiązku zachodzi konieczność uiszczenia opłaty produktowej. Przedsiębiorcy samodzielnie określają należną opłatę produktową i przekazują ją na konto właściwego terytorialnie urzędu marszałkowskiego. Ostatecznym adresatem środków pieniężnych z opłat produktowych jest niemal w całości Narodowy Fundusz Ochrony Srodowiska i Gospodarki Wodnej.

Opłaty produktowe za sprzęt elektryczny i elektroniczny podlegają niemal identycznym regułom, co opłaty produktowe za opakowania, baterie i akumulatory, oleje smarowe oraz opony. Występują jedynie dwie różnice. W przypadku sprzętu elektrycznego i elektronicznego obok odzysku i recyklingu obowiązują dodatkowo poziomy zbierania odpadów. Ponadto środki z opłat produktowych za sprzęt elektryczny i elektroniczny przedsiębiorcy przekazują do Narodowego Funduszu Ochrony Środowiska i Gospodarki Wodnej, ale za pośrednictwem wojewódzkich funduszy ochrony środowiska i gospodarki wodnej ${ }^{6}$.

Opłaty za usuwanie drzew i krzewów zobowiązani są ponosić wszyscy posiadacze nieruchomości wycinający z nich drzewa lub krzewy. Stawki opłat są zróżnicowane w zależności od rodzaju drzewa i grubości pnia. Opłaty nalicza na ogół wójt, burmistrz albo prezydent miasta jako organ właściwy do wydania zezwolenia na usunięcie drzew lub krzewów, a nie sam posiadacz nieruchomości. Występuje jednak szereg zwolnień z obowiązku uiszczania opłat za usuwanie drzew i krzewów. Wpłaty dokonuje się na konto właściwego terytorialnie urzędu gminy?

Opłaty za brak sieci zbierania wyeksploatowanych pojazdów nakładane są głównie na podmioty gospodarcze (producenci, importerzy) wprowadzające pojazdy samochodowe na rynek polski. W przypadku, gdy liczba tych pojazdów wynosi co najmniej tysiąc na rok, wspomniane podmioty są zobowiązane do zapewnienia tzw. sieci zbiórki wyeksploatowanych pojazdów. Podmioty niezapewniające sieci zbiórki zmuszone są ponieść taką opłatę. Obowiązek ten dotyczy także osób fizycznych sprowadzających pojazdy samochodowe z zagranicy na własne potrzeby. Środki z opłat za brak sieci zbierania wyeksploatowanych pojazdów stanowią w całości przychód Narodowego Funduszu Ochrony Środowiska i Gospodarki Wodnej.

Opłaty za substancje zubożające warstwę ozonową ponoszą podmioty wprowadzające je po raz pierwszy do obrotu na terytorium Polski. Odnosi się to generalnie do dwóch grup substancji, tj. wodorochlorofluorowęglowodorów (HCFC) oraz chlorofluorowęglowodorów (CFC). Podmioty zobowiązane do wniesienia tej opłaty obliczają jej wysokość i wpłacają należne środki na konto właściwego

\footnotetext{
${ }^{6}$ Pewne zmiany w tym względzie wprowadziła ustawa z dnia 24 kwietnia 2009 r. o bateriach i akumulatorach, Dz. U. z 2009 r., nr 79, poz. 666.

${ }^{7}$ Do końca 2009 r. na konto gminnego funduszu ochrony środowiska i gospodarki wodnej.
} 
urzędu marszałkowskiego. Wpływy pochodzące z opłat za substancje zubożające warstwę ozonową przekazywane są prawie w całości na konto Narodowego Funduszu Ochrony Środowiska i Gospodarki Wodnej.

Opłaty zastępcze za niewykupienie wymaganej ilości energii odnawialnej wiążą się z koniecznością zapewnienia określonego udziału energii elektrycznej wytwarzanej w odnawialnych źródłach w jej krajowym zużyciu. Obowiązek uiszczenia opłaty zastępczej ponoszą - w określonych przypadkach - przedsiębiorstwa zajmujące się wytwarzaniem energii elektrycznej i jej obrotem. Dotyczy to sytuacji, gdy nie uzyskają one i nie przedstawią do umorzenia Prezesowi Urzędu Regulacji Energetyki (URE) tzw. świadectwa pochodzenia, będącego potwierdzeniem wytworzenia energii w odnawialnym źródle. Opłaty zastępcze za niewykupienie wymaganej ilości energii odnawialnej stanowią w całości dochód Narodowego Funduszu Ochrony Środowiska i Gospodarki Wodnej.

Opłatą paliwową objęte jest wprowadzanie na rynek krajowy paliw silnikowych oraz gazu, wykorzystywanych do napędu pojazdów, a obowiązek jej zapłaty ciąży zarówno na producentach i importerach paliw silnikowych lub gazu, jak i na podmiotach dokonującym nabycia wewnątrzwspólnotowego. Środki pochodzące $\mathrm{z}$ opłaty paliwowej stanowią w $80 \%$ przychód Krajowego Funduszu Drogowego z przeznaczeniem na budowę, remonty oraz utrzymanie dróg i autostrad. Natomiast pozostała jej część przekazywana jest do Funduszu Kolejowego.

Należy dodać, iż ustalona lista podatków związanych ze środowiskiem jest w pewnej części rozbieżna $\mathrm{z}$ wynikami badań naukowych $\mathrm{w}$ tym zakresie. Jest to po części zrozumiałe - wiadomo, że występuje szereg trudności, a nawet kontrowersji przy definiowaniu i opisywaniu ich istoty, a także określaniu, co jest podatkiem ekologicznym, a co opłatą tego rodzaju. Szczególnie wiele wątpliwości budzi przypisanie tym instrumentom charakteru ,proekologiczności”, co decyduje o zaliczeniu ich do grupy podatków (opłat) ekologicznych. Rodzi się bowiem pytanie, czy przedmiot danego podatku ma związek z uciążliwością dla środowiska. A jeśli tak, to jaki jest stopień tego powiązania? W ślad za tym powstaje też inne pytanie: czy dany podatek należy uznać za ekologiczny czy nie? Dobrym przykładem może tu być stosowany w wielu krajach podatek pobierany przy rejestracji samochodów (Małecki 2012b: 35-36).

Lista podatków związanych ze środowiskiem zaprezentowana w tab. 2 zawiera w sobie opłaty celne na towary szczególnie szkodliwe dla środowiska (głównie w fazie użytkowania). Są to: pojazdy, statki powietrzne, jednostki pływające $\mathrm{i}$ inne urządzenia transportowe oraz paliwa mineralne, oleje mineralne, produkty ich destylacji i substancje pochodne. Tymczasem w dotychczasowych badaniach opłat celnych nie wymieniano w ogóle w grupie opłat ekologicznych. Natomiast 
opłaty rejestracyjne i ewidencyjne pojazdów oraz opłata paliwowa były jedynie wspominane jako możliwe do zakwalifikowania do grupy opłat ekologicznych (Małecki 2012b: 157). Z drugiej strony lista przyjęta przez GUS na potrzeby sprawozdawczości Eurostatu nie zawiera stosunkowo wielu obciążeń finansowych uznawanych za podatki bądź opłaty ekologiczne i wymienianych w literaturze naukowej. Są to:

- podatek rolny,

- podatek leśny,

- opłaty za pobór wód podziemnych i powierzchniowych,

- opłaty za składowanie odpadów,

- opłaty za działalność górniczą (koncesyjne i eksploatacyjne),

- opłaty i należności z tytułu użytkowania obiektów i obszarów związanych z gospodarką wodną (należności za korzystanie ze śródlądowych dróg wodnych oraz urządzeń wodnych, opłaty za oddanie w użytkowanie niektórych gruntów pokrytych wodami, opłaty za oddanie w użytkowanie obwodów rybackich, opłaty za udostępnianie danych $\mathrm{z}$ katastru wodnego),

- opłaty z tytułu handlu uprawnieniami do emisji,

- opłaty z tytułu składania wniosków o pozwolenie zintegrowane,

- należności i opłaty za wyłączenie gruntów rolnych z produkcji,

- należności i opłaty za wyłączenie gruntów leśnych z produkcji,

- odpis od wartości sprzedaży drewna,

- opłaty podwyższone i dodatkowe.

W szczególności poważne wątpliwości budzi nieuwzględnienie na liście przyjętej przez GUS na potrzeby sprawozdawczości Eurostatu obowiązujących w Polsce podatków związanych ze środowiskiem: opłat za umieszczane odpadów na składowisku, opłat za pobór wód, jak również opłat za działalność górniczą. Pomimo jednoznacznej interpretacji Eurostatu, w myśl której obciążeń finansowych związanych z gospodarowaniem powierzchnią ziemi nie powinno się zaliczać do podatków związanych ze środowiskiem, wydaje się, że obowiązujące w Polsce opłaty za umieszczanie odpadów na składowisku (składowanie odpadów) są ewidentnie opłatami ekologicznymi, a więc mieszczą się w szeroko rozumianej definicji ,podatków związanych ze środowiskiem”. Stanowią one bowiem odpłatność za wprowadzanie zanieczyszczeń do zasobów środowiska (jakim jest także powierzchnia ziemi), a więc oddziałują w sposób negatywny na to środowisko, tak samo jak niepominięte na liście opłaty za emisję gazów i pyłów, stanowiące odpłatność za wprowadzanie zanieczyszczeń do powietrza. Także nieujęte na tej liście opłaty za pobór wód stanowią odpłatność za wykorzystywanie na dużą skalę zasobów naturalnych (jakimi są również zasoby wodne), co negatywnie wpływa na środowisko. Opłaty za działalność górniczą (eksploatacyjne i koncesyjne) natomiast stanowią, zgodnie z interpretacją Eurostatu, swoistą rentę zasobową (jeżeli właścicielem jest $\mathrm{w}$ danych warunkach podmiot publiczny za- 
miast prywatnego), stąd też według takiej wykładni nie powinno się ich zaliczać do podatków związanych ze środowiskiem. Interpretacja ta stoi jednak w sprzeczności z przyjętą definicją, w myśl której za podatek związany ze środowiskiem uważa się opłatę, dla której podstawą obciążenia (opodatkowania) jest jednostka fizyczna czegoś, co ma udowodniony określony negatywny wpływ na środowisko. Negatywne oddziaływanie na środowisko działalności górniczej jest bowiem bezsprzeczne.

Pozostałe pominięte przez GUS podatki i opłaty ekologiczne nie budzą tak dużych wątpliwości, bądź też ich pominięcie jest świadome - jak w przypadku opłat podwyższonych i dodatkowych. Uzyskanie bowiem informacji co do wielkości pochodzących z nich wpływów jest dość trudne, a poza tym wielkości te nie są znaczne.

Stosunkowo prostym zadaniem było przyporządkowanie poszczególnych (wymienionych w tab. 2) podatków związanych ze środowiskiem do wyszczególnionych grup rodzajowych: energia, transport, zanieczyszczenia środowiska, zasoby naturalne. Przyporządkowanie to wynika wprost z charakteru (rodzaju) podstawy obciążenia (opodatkowania) danego podatku czy też opłaty. Wspomnianego przyporządkowania dokonano, uwzględniając opisane wcześniej uwarunkowania, które dotyczyły niejednoznaczności odniesienia do danej grupy rodzajowej, czy też pewnych, narzuconych przez Eurostat, ogólnych reguł w tym zakresie. Zostało to zaprezentowane w tej samej tab. 2.

Natomiast najtrudniejszym do rozstrzygnięcia problemem jest przyporządkowanie zidentyfikowanych podatków związanych ze środowiskiem do wydzielonych grup zgodnie z NACE Rev. 2 w układzie A*64. Precyzyjne ustalenie takiego przyporządkowania wymagałoby szczegółowych badań, co byłoby bardzo pracochłonne, a zatem - nieuzasadnione. Na podstawie własnych analiz i przemyśleń, jak też konsultacji z ekspertami, dokonano takiego przyporządkowania, mając na uwadze, że niektóre przedstawione propozycje mogą być uznane za dyskusyjne. W kilku wątpliwych przypadkach, to jest w odniesieniu do określonych grup (NACE Rev. 2 w układzie A*64), w których wystąpienie poszczególnych rodzajów podatków związanych ze środowiskiem jest tylko możliwe, kierowano się wielkością spodziewanych środków pieniężnych $\mathrm{z}$ nich pochodzących (bazując na danych $\mathrm{z}$ lat poprzednich). Pominięto zatem te grupy, w ramach których podatki związane ze środowiskiem mogą nie być w ogóle uiszczane, bądź też skala tego jest niewielka. Ostateczne przyporządkowanie obowiązujących w Polsce zidentyfikowanych podatków związanych ze środowiskiem do wydzielonych grup zgodnie z NACE Rev. 2 w układzie A*64 zostało przedstawione $\mathrm{w}$ tab. 3. Łatwo dostrzec, że większość z podatków tego rodzaju jest ponoszonych przez podmioty zaliczone do wszystkich wydzielonych grup działalności gospodarczych. 
Przyporządkowanie zidentyfikowanych podatków związanych ze środowiskiem do grup NACE Rev. 2 w układzie A*64

\begin{tabular}{|c|c|}
\hline Rodzaj podatku związanego ze środowiskiem & $\begin{array}{c}\text { Przyporządkowanie do grup NACE Rev. } 2 \\
\text { w układzie A*64 }\end{array}$ \\
\hline Akcyza na paliwa przeznaczone do celów opałowych & wszystkie grupy \\
\hline $\begin{array}{l}\text { Akcyza na paliwa przeznaczone do celów } \\
\text { napędowych }\end{array}$ & wszystkie grupy \\
\hline Akcyza na gaz LPG & wszystkie grupy \\
\hline Akcyza na energię elektryczną & wszystkie grupy \\
\hline Akcyza na samochody osobowe & wszystkie grupy \\
\hline Akcyza na oleje smarowe & wszystkie grupy \\
\hline $\begin{array}{l}\text { Opłaty celne na importowane: paliwa mineralne } \\
\text { oleje mineralne i produkty ich destylacji } \\
\text { substancje bitumiczne woski mineralne }\end{array}$ & $\mathrm{B}, \mathrm{C} 19, \mathrm{C} 23, \mathrm{C} 24, \mathrm{D} 35$ \\
\hline $\begin{array}{l}\text { Opłaty celne na importowane: pojazdy } \\
\text { statki powietrzne jednostki pływające oraz } \\
\text { współdziałające urządzenia transportowe }\end{array}$ & wszystkie grupy \\
\hline Opłaty rejestracyjne i ewidencyjne pojazdów & wszystkie grupy \\
\hline Podatek od środków transportowych & $\begin{array}{l}\text { A01, A02, A03, B, C10-12, C13-15, C16, } \\
\text { C17, C18, C19, C20, C21, C22, C23, C24, } \\
\text { C25, C26, C27, C28, C29, C30, C31-32, } \\
\text { C33, D35, E36, E37-39, F41-43, G45, } \\
\text { G46, G47, H49, H50, H51, H52, H53, I55- } \\
\text { 56, J58, J59-60, J61, N79, N80-82, O84 }\end{array}$ \\
\hline Opłaty za odprowadzanie ścieków & $\begin{array}{l}\text { A01, B, C10-12, C13-15, C16, C17, C19, } \\
\text { C20, C21, C22, C23, C24, D35, E37-39 }\end{array}$ \\
\hline Opłaty za emisję gazów i pyłów & wszystkie grupy \\
\hline Opłaty produktowe za opakowania & wszystkie grupy \\
\hline Opłaty produktowe za oleje smarowe & wszystkie grupy \\
\hline Opłaty produktowe za opony & wszystkie grupy \\
\hline Opłaty produktowe za baterie i akumulatory & wszystkie grupy \\
\hline $\begin{array}{l}\text { Opłaty produktowe za sprzęt elektryczny } \\
\text { i elektroniczny }\end{array}$ & wszystkie grupy \\
\hline Opłaty za usuwanie drzew i krzewów & wszystkie grupy \\
\hline $\begin{array}{l}\text { Opłaty za brak sieci zbierania wyeksploatowanych } \\
\text { pojazdów }\end{array}$ & wszystkie grupy \\
\hline Opłaty za substancje zubożające warstwę ozonową & $\mathrm{C} 27, \mathrm{C} 28, \mathrm{D} 35$ \\
\hline $\begin{array}{l}\text { Opłaty zastępcze za niewykupienie wymaganej } \\
\text { ilości energii odnawialnej }\end{array}$ & D35, G46 \\
\hline Opłata paliwowa & $\mathrm{B}, \mathrm{C} 19, \mathrm{C} 23, \mathrm{D} 35$ \\
\hline
\end{tabular}

Źródło: opracowanie własne na podstawie: Małecki (2012a): 35-36. 


\section{PODSUMOWANIE}

Unia Europejska kieruje do krajów członkowskich, za pośrednictwem Eurostatu, nowe wymagania co do jednolitego ujmowania obowiązujących w tych krajach podatków i opłat ekologicznych jako ,podatków związanych ze środowiskiem" oraz tworzenia jednolitej sprawozdawczości statystycznej w tym zakresie. Zadania te implikują szereg problemów metodycznych dotyczących identyfikowania jako „podatków związanych ze środowiskiem” różnych występujących w Polsce opłat i podatków ekologicznych, jak również tworzenia procesu przygotowywania danych sprawozdawczych w wymaganych przez Eurostat układach. W tym drugim przypadku następuje konieczność przyporządkowania poszczególnych zidentyfikowanych podatków związanych ze środowiskiem do jednej z czterech grup rodzajowych: energia, transport, zanieczyszczenia środowiska i zasoby naturalne, a następnie ich odniesienia do wydzielonych grup działalności gospodarczej według obowiązującej w Unii Europejskiej klasyfikacji NACE Rev. 2.

$\mathrm{W}$ artykule dokonano identyfikacji licznych obowiązujących w Polsce opłat i podatków ekologicznych jako ,podatków związanych ze środowiskiem”, zgodnie z definicją Eurostatu (tab. 2). Warto zwrócić uwagę, że jest to w pewnej części rozbieżne $\mathrm{z}$ dotychczasowymi ustaleniami badawczymi w tym zakresie. Dokonano także zaklasyfikowania zidentyfikowanych podatków do wyszczególnionych grup rodzajowych (tab. 2). Ponadto, podjęto trudną próbę ich przyporządkowania do wydzielonych grup działalności gospodarczej (tab. 3). Zaprezentowany materiał może być pomocny dla GUS przy tworzeniu całego procesu przygotowywania na potrzeby Eurostatu danych sprawozdawczych dotyczących obowiązujących w Polsce podatków związanych ze środowiskiem, co jest wymagane w świetle nowych regulacji prawnych Unii Europejskiej.

\section{BIBLIOGRAFIA}

Bartniczak B., Ptak M. (2011), Optaty i podatki ekologiczne. Teoria i praktyka, Wrocław. Environmental Taxes. A Statistical Guide. 2013 edition (2013), Eurostat/European Union.

Małecki P. P. (2012a), Opracowanie metodologii rachunku podatków zwiazanych ze środowiskiem w zakresie alokacji wielkości zagregowanych w podziale na grupy podatków i rodzajów dziatalności wedlug NACE Rev. 2, projekt finansowany ze środków Unii Europejskiej (w 70\%) na podstawie umowy o dotację podpisanej pomiędzy Komisją Europejską/Eurostatem a Głównym Urzędem Statystycznym.

Małecki P. P. (2012b), System opłat i podatków ekologicznych w Polsce na tle rozwiąań w krajach $O E C D$, Kraków.

Małecki P. P. (2013), Ocena metodologii alokacji kwot podatków i oplat zwiazanych ze środowiskiem $w$ ramach modułu rachunków podatków związanych ze środowiskiem dla europejskich rachunków ekonomicznych środowiska, projekt finansowany ze środków Unii Europejskiej (w 70\%) na podstawie umowy o dotację podpisanej pomiędzy Komisją Europejską/Eurostatem a Głównym Urzędem Statystycznym. 
Rozporządzenie Parlamentu Europejskiego i Rady (UE) nr 691/2011 z dnia 6 lipca 2011 r. w sprawie europejskich rachunków ekonomicznych środowiska, Dz. Urz. L 192 z 22.07.2011.

Taxation, Innovation and the Environment (2010), OECD, http://www.oecd.org/env/tools-evaluation/taxationinnovationandtheenvironment.htm (dostęp: 10.09.2014).

Ustawa z dnia 24 kwietnia 2009 r. o bateriach i akumulatorach, Dz. U z 2009 r., nr 79, poz. 666.

Piotr P. Małecki

\title{
THE MAIN METHODICAL ELEMENTS OF DATA REPORTING PREPARATION PROCESS ON ENVIRONMENTALLY RELATED TAXES IN LIGHT OF THE NEW EUROPEAN UNION LEGAL FRAMEWORK
}

\begin{abstract}
The paper covers methodical problems with the process of preparation of reporting data referring to environmentally related taxes being in force in Poland. The need to create this reporting process is due to the new European Union regulations, which impose on Member States the obligation to communicate accurately prepared data to Eurostat. In this paper the author tries to resolve certain methodological dilemmas in this respect. First of all it was necessary to determine a list of environmentally related taxes being in force in Poland, in accordance with the definition of Eurostat. Other methodological problems, taken in the article relate to the allocation of identified environmentally related taxes into one of four generic groups (energy, transport, pollution and natural resources), and then referencing them to the groups of economic activities in the EU (in accordance with the classification NACE Rev. 2). Such classification is required by the new EU regulations. In the article the author also analyzes the existing definition of ecological taxes (and fees) defined uniformly as "environmentally related taxes" in light of the latest interpretation of the Eurostat. The paper also presents legal conditions relating to the whole process of creating statistical reporting of these taxes.
\end{abstract}

Keywords: statistical reporting, environmentally related taxes, legal regulations, European Union. 